\title{
Evaluation of Newly Released Soybean Varieties (Glycine max.) under Smallholder Farmers' Condition in Western Ethiopia
}

\author{
Takele Atnafu Delele ${ }^{*} \quad$ Yaregal Fekadu Simachew Dirshaye Hailu Gebre Talefe Ayele Zenebe \\ Department of Agricultural Extension and Communication Research, Ethiopian Institute of Agricultural \\ Research, Pawe Agricultural Research Center, Pawe, Ethiopia
}

\begin{abstract}
Soybean is a miracle legume crop in the world due to its multipurpose use. The global demand of the crop is increasing rapidly because of its growing demand particularly in the animal feed industries. But, the current production status of the commodity is not comparable to the rapidly increasing demands. The main objective of this study was to evaluate the performance of improved soybean varieties under smallholder farmers' condition in western Ethiopia. Six kebeles were selected purposively in Pawe and Jawe districts based on their potential and suitability for soybean production. A total of 24 hosted farmers were selected purposively by considering their willingness and performance to implement the demonstration. Pawe-1, Pawe-2, Pawe-3 and EthioYugoslavia varieties were the materials used in the evaluation. Grain yield, seed size, pod number per plant, seed number per pod, plant height, disease resistant and maturity date were the main preference traits for farmers. Bothe qualitative and quantitative data were collected from 41 farmers (17 control group). The collected data were analyzed through descriptive and inferential statistics by using SPSS software package. Farmers' preference ranking also conducted based of their selection criteria. The combined results over locations show that $1767.58,1723.46,1619.58$ and $1600.08 \mathrm{~kg} \mathrm{ha}^{-1}$ mean grain yield recorded from Pawe-3, Ethio-Yugoslavia, Pawe-1 and Pawe-2 varieties respectively. Overall mean grain yield of improved varieties was $1677.68 \mathrm{~kg} \mathrm{ha}^{-1}$. The least $\left(927.41 \mathrm{~kg} \mathrm{ha}^{-1}\right)$ mean grain yield observed from the local variety. Findings revealed that all the demonstrated improved varieties have significant yield advantage over the control at $(\mathrm{p}<0.01)$ in all locations. Farmers put Pawe-3 variety in the first rank based on the total score of their preference traits. Agricultural professionals and other concerned bodies have to give more emphasis to promote the newly released proven soybean varieties with full recommended packages to increase the production status further to ensure the demands of domestic processing and export marketing and this will contribute to the overall economic growth.

Keywords: Demonstration, farmers' preference, soybean variety, western Ethiopia
\end{abstract}

DOI: $10.7176 / \mathrm{JNSR} / 12-13-04$

Publication date:July $31^{\text {st }} 2021$

\section{Introduction}

Soybean (Glycine max.) is one of the most important and widely grown legume crops worldwide due to its multipurpose use particularly in the animal feed industries and human nutrition. Its high quality protein and balanced amino acid profile in ration formulation and human diets are the driving forces of soybean production(Shea et al., 2020). The global average production of soybean reached 334.89 million tons per annum. The Americas is the top soybean producer continent in the world followed by Asia, Europe and Africa. The findings of this study indicate that $87.1 \%$ of global soybean production covered by Americas. Soybean was introduced to Sub-Saharan Africa through Chinese traders in the $19^{\text {th }}$ century for the first time. It was cultivated as a commercial crop in the early 1903 in South Africa(Khojely et al., 2018). Large-scale commercial and smallscale farmers have the respective share of $80 \%$ and 20 in global soybean production(Voora et al., 2020). Ethiopia has huge potential for soybean production although the current production status is not comparable to the existing potential(Tesfaye et al., 2018). The production trends of soybean are not constantly increasing over time due to market price fluctuation and lack of awareness about local processing of the crop. This price fluctuation and low level of awareness about its utilization have their own negative implication on farmers motivation regarding soybean production(Fentahun, 2019). Oil crops in general and soybean in particular play an indispensible role to ensure national food security, increase smallholder farmers' income and increase export earnings particularly for developing countries including Ethiopia. Despite its high production potential and economic importance, the level of adoption of improved soybean varieties and dissemination constrained by many factors(Abebe, 2018). Findings of this study suggest that education level of household head, farm experience, credit access, training, age and market distance statistically significant factors to adopt improved soybean varieties. Although Ethiopia started soybean research in the early 1950 's, its productivity is below potential and far from other soybean producer countries. Promising progress has been recorded particularly in the breeding program focusing on the breeding objectives of grain yield, disease resistance, resistance of shattering and maturity (Getnet, 2019).

Low productivity of the crop is always associated with lack appropriate production technologies(Adebayo et al., 2018). Use of improved soybean variety had a positive and significant effect on crop productivity. 
Findings of this study suggest that $61 \%$ of yield gain and income increment achieved for adopters of improved varieties(Tufa et al., 2019). Adoption of improved soybean variety/ies couple with new management practices positively and significantly impacted on soybean productivity and farmers' income. The results of propensity score matching (PSM) in this study revealed that soybean productivity increased by $15 \%$ for those farmers who adopted improved soybean variety(Teshale, 2019). Planting of soybean in the optimal dates potentially increased the productivity of soybean varieties(Fedorova et al., 2020). Benishangul Gumuz is one the potential regions of Ethiopia in soybean production. The crop is producing in all the three administrative zones of the region. Existence of Pawe agricultural research center (which coordinates soybean research at national level), suitable lands, rain fall distribution, temperature and others are great opportunities to produce soybean intensively. The region has more than 156,000 hectares of land which are suitable for soybean production(Kedir, 2019). Although the region has untapped potential regarding soybean production, its production is below the existing potential due to lack of using improved soybean varieties with recommended agronomic packages, market price fluctuation and low level awareness for its utilization. Overall, this study focusing on evaluation of improved soybean varieties through on farm demonstration under smallholder farmers' condition and this can improve the uptake of appropriate production technologies.

\section{Materials and Methods}

\subsection{Description of the study area}

The evaluation was conducted under Pawe and Jawe districts of western Ethiopia due to their soybean production potential. The two districts were selected purposively since they are the major soybean producers in

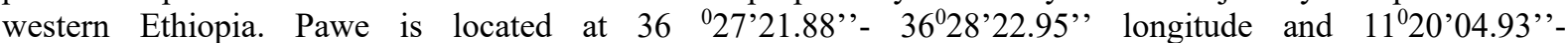
$11^{\circ} 17^{\prime} 50.43^{\prime}$ 'latitude and $567 \mathrm{~km}$ away from Addis Ababa. According to the data found form district government, Pawe had a total population of $64,431(51.68 \%$ male). The total area of the district is 64,300 hectare off which $44 \%$ is arable. Average annual rain fall and temperature are $1586 \mathrm{~mm}$ and $32.7^{\circ} \mathrm{c}$ with altitude of 1120 m.a.s.l. More than $35 \%$ of cultivated land was allocated for soybean production since the area is known with its soybean potential. Existence of suitable agro ecology and about 30 newly released soybean varieties are great opportunities to the district to produce soybean in large-scale(Ayalew et al., 2018). Similarly, Jawe district is located $602 \mathrm{~km}$ away from Addis Ababa with geographical location of 36 $26^{\prime} 17.58^{\prime}$ " longitude and of $11^{0} 33^{\prime} 22.68^{\prime}$ ' latitude. Jawe district has a total area of 515,400 hectare with an estimated population of 122,259 (53.08\% male) inhabitants. The district has annual average rain fall of $1250 \mathrm{~mm}$ which ranges $700-1500$ m.a.s.1. maize, sorghum, soybean, ground nut, fingure millet and sesame are the dominant crops producing in western Ethiopia.

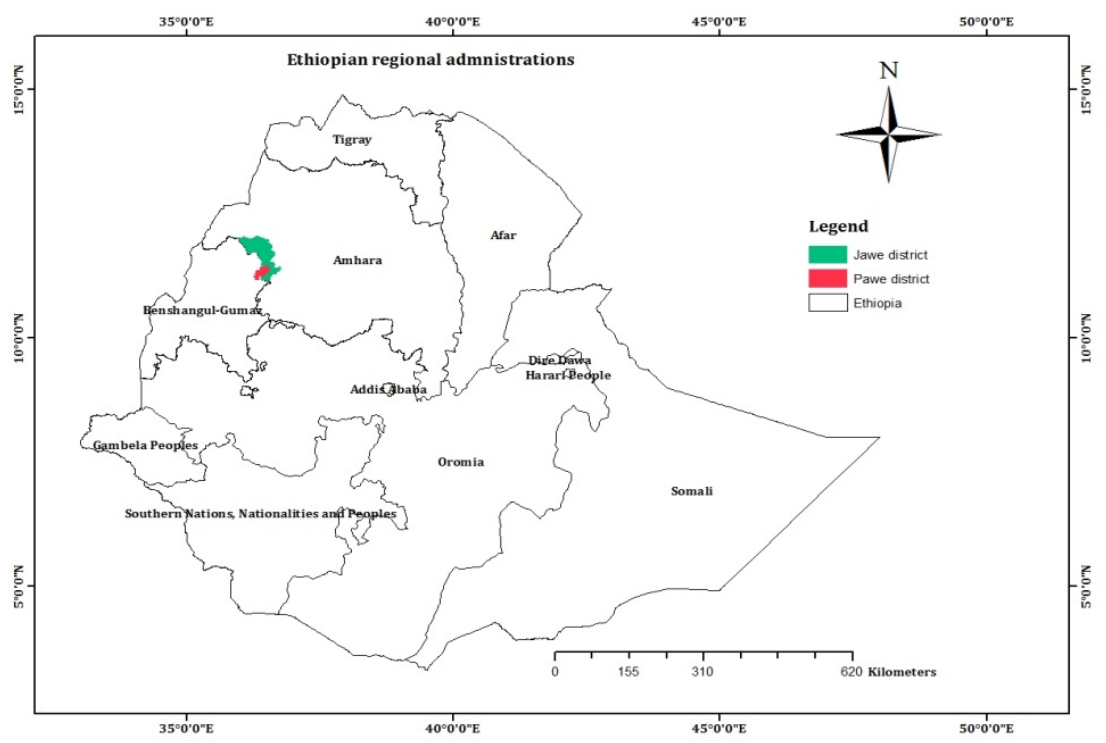

Figure 1. Map of the study area (Pawe \& Jawe districts)

\subsection{Farmers selection and field establishment}

The on farm demonstration was conducted under Pawe and Jawe districts of western Ethiopia due to their potentials of soybean production. Similarly, the six kebeles under the two districts were selected based on their soybean potential and performance. Four kebeles namely village 4, village $28 / 29$, village 26 and village $23 / 45$ were selected purposively from pawe. Simida and alikurand kebeles were selected and used in Jawe district. A total 24 hosted farmers were selected purposively by considering their willingness and performance to 
implement the demonstration with close guidance of development agents and experts. Additionally, 17 farmers who were producing soybean by using locally available seeds were used as a control in the same kebeles. The fields of each participant farmer were considered as replication. Full technology packages of soybean were provided to farmers. Both theoretical and practical trainings organized accordingly before the activities get started. Each hosted farmer prepared $25 \mathrm{~m}^{*} 25 \mathrm{~m}\left(625 \mathrm{~m}^{2}\right)$ plot of land for each variety and planted accordingly. All the demonstrated four varieties were planted side by side and evaluated properly. The varieties planted $5 \mathrm{~cm}^{*} 60 \mathrm{~cm}$ of plant and row spacing respectively with recommended seed rate of $70 \mathrm{~kg} \mathrm{ha}^{-1}$. A blanket recommendation of $100 \mathrm{~kg} \mathrm{ha}^{-1}$ NPS fertilizer was applied. Weeding, insect and pest control and other farming operations were implemented. Researchers and experts were monitored and evaluated each activity accordingly as the schedule with development agents and hosted farmers at different stages of the crop. During field visit, feed backs of participant was collected and recorded properly.

\subsection{Planting materials}

In the overall process of on farm demonstration, four adapted and improved soybean varieties (Pawe-1, Pawe-2, Pawe-3 and Ethio-Yugoslavia) were used from pawe agricultural research center.

\subsection{Data collection and analysis}

Both qualitative and quantitative data were collected by the researchers from the field and in the homestead of each hosted farmer. Similarly, data were collected from the control group in the same locations. Data of yield and yield components of each crop variety recorded carefully to compare the yield to the control group. Farmer's perception and preference on the demonstrated varieties were recorded during the evaluation process and directly on the spot. Finally, the collected data were analyzed through descriptive and inferential statistics by using SPSS (version 26) software package. Farmers' preference ranking also conducted based on their selection criteria.

\section{Results and Discussion}

\subsection{Capacity building training}

Capacity building training on soybean production and management practices with full recommended packages were provided to 24 hosted farmers and development agents who were working in the study area. The training well organized and incorporated both theoretical and practical sessions.

\subsection{Yield Performance of the demonstration}

The grain yield data were collected both from 24 hosted farmers and other 17 farmers who produced soybean by using locally available variety seeds as a control. As the results depicted in Table 1, the maximum average yield was recorded from Pawe-3 variety (1760.19 $\left.\mathrm{kg} \mathrm{ha}^{-1}\right)$ at Pawe district followed by Ethio-Yugoslavia (1726 kg ha$\left.{ }^{1}\right)$. Average yield of 1677.19 and $1639.31 \mathrm{~kg} \mathrm{ha}^{-1}$ was recorded in Pawe-1 and Pawe-2 varieties respectively. The least average yield of soybean observed $\left(840 \mathrm{~kg} \mathrm{ha}^{-1}\right)$ from the local check variety with high degree of farmers' variability at SD of 490.60 . The finding indicates that all the improved demonstrated varieties dominated the locally available control variety regarding grain yield.

Table 1. Mean grain yield of the demonstrated varieties in Pawe

\begin{tabular}{lllll}
\hline \multirow{2}{*}{ variety } & \multicolumn{3}{c}{ Grain yield (kg ha) } \\
\cline { 2 - 5 } & Minimum & Maximum & Mean & SD \\
\hline Pawe-1 & 1232.00 & 2400.00 & 1677.19 & 256.45 \\
Pawe-2 & 1200.00 & 2480.00 & 1639.31 & 278.87 \\
Pawe-3 & 1367.00 & 2240.00 & 1760.19 & 240.51 \\
Ethio-Yugoslavia & 1280.00 & 2400.00 & 1726.00 & 300.91 \\
Local variety & 300.00 & 1733.00 & 840.00 & 490.60 \\
\hline
\end{tabular}

Source: Own computation from data, 2020

The results indicated in Table 2 showed that the average grain yield of soybean for local seed users was $840.00 \mathrm{~kg} \mathrm{ha}^{-1}$ with a standard deviation of 490.60. Similarly, average grain yield of soybean for improved seed users was $1700.67 \mathrm{~kg} \mathrm{ha}^{-1}$. The t-test (t-value $\left.=-5.93, \mathrm{p}<0.01\right)$ is a statistical evidence for the existence significant mean difference regarding grain yield between local seed users and improved seed users at $(p<0.01)$. The negative sign of t-value (-5.93) implies that those farmers who produce soybean by using locally available variety obtain less grain yield as compared to improved seed users. The result agrees with(Teshale, 2019) who confirmed that adoption of improved soybean variety significantly and positively correlated with crop productivity. 
Table 2. Statistical test of local and improved varieties in terms of grain yield (Pawe)

\begin{tabular}{lllll}
\hline variables & Mean Grain yield $\left(\mathrm{kg} \mathrm{ha}^{-1}\right)$ & SD & t-value & Sig. value \\
\hline local seed users & 840.00 & 490.60 & -5.93 & 0.000 \\
improved seed users & 1700.67 & 251.27 & & \\
\hline
\end{tabular}

Source: Own computation from data, 2020

The results of the demonstration showed that the maximum grain yield recorded from Pawe- 3 and EthioYugoslavia varieties $\left(2112 \mathrm{~kg} \mathrm{ha}^{-1}\right)$ in Jawe district. The study results indicated in Table 3 indicates that all the demonstrated improved varieties showed significant yield increment over the control local variety. The maximum average yield observed from Pawe-3 variety (1782.38 $\mathrm{kg} \mathrm{ha}^{-1}$ ) followed by Ethio-Yugoslavia (1718.38 $\mathrm{kg} \mathrm{ha}^{-1}$ ) at Jawe as Pawe district. Average grain yield of Pawe-1 and Pawe-2 varieties in the demonstration was 1504.38 and $1521.63 \mathrm{~kg} \mathrm{ha}^{-1}$ respectively. The least $\left(1052.29 \mathrm{~kg} \mathrm{ha}^{-1}\right.$ yield observed for the local check variety.

Table 3. Mean yield of the demonstrated varieties in Jawe district

\begin{tabular}{lllll}
\hline \multirow{2}{*}{ variety } & \multicolumn{3}{c}{ Grain yield (kg ha) } \\
\cline { 2 - 5 } & Minimum & Maximum & Mean & SD \\
\hline Pawe-1 & 1416.00 & 1640.00 & 1504.38 & 72.86 \\
Pawe-2 & 1304.00 & 1824.00 & 1521.63 & 147.11 \\
Pawe-3 & 1392.00 & 2112.00 & 1782.38 & 198.23 \\
Ethio-Yugoslavia & 1392.00 & 2112.00 & 1718.38 & 201.48 \\
Local variety & 100.00 & 1500.00 & 1052.29 & 465.41 \\
\hline
\end{tabular}

Source: Own computation from data, 2020

The results indicated in Table 4 showed that the mean grain yield of improved seed users and non-users was 1631.69 and $1052.29 \mathrm{~kg} \mathrm{ha}^{-1}$ respectively. High yield variability $(\mathrm{SD}=465.41)$ observed from local seed users as compared to their counter parts. The result of T-test $(\mathrm{t}=-3.34, \mathrm{p}<0.01)$ is an evidence for the existence of significant mean difference between improved seed users and non-users regarding grain yield at $(p<0.01)$. The negative sign of $t$-value implies that local seed users produce less output of soybean per hectare as compared to improved seed users.

Table 4. Statistical test of local and improved varieties (grain yield)

\begin{tabular}{lllll}
\hline variables & Mean Grain yield $\left(\mathrm{kg} \mathrm{ha}^{-1}\right)$ & SD & t-value & Sig. value \\
\hline local seed users & 1052.29 & 465.41 & -3.34 & 0.005 \\
improved seed users & 1631.69 & 152.34 & & \\
\hline
\end{tabular}

Source: Own computation from data, 2020

The combined data of the experiments over the two locations showed that all the demonstrated improved soybean varieties well performed and dominated the local varieties. The combined results depicted in Table 5 indicates that the maximum grain yield observed from Pawe-3 variety $\left(1767.58 \mathrm{~kg} \mathrm{ha}^{-1}\right)$ implies that the variety is the best preferred by the farmers due to its high grain yield as compared to others. Ethio-Yugoslavia variety was the $2^{\text {nd }}$ high yielder next to Pawe-3. Pawe-1 and Pawe-2 varieties brought the respective grain yield of 1619.58 and $1600.08 \mathrm{~kg} \mathrm{ha}^{-1}$. Producers received $927.41 \mathrm{~kg} \mathrm{ha}^{-1}$ from the locally available seeds which is the least as compared to the improved varieties used by hosted farmers. Overall findings of this study revealed that significant yield difference observed between improved seed users and local seed users.

Table 5. Combined mean yield of the demonstrated improved varieties

\begin{tabular}{lllll}
\hline variety & \multicolumn{3}{l}{ Grain yield (kg ha) } \\
\cline { 2 - 5 } & Minimum & Maximum & Mean & SD \\
\hline Pawe-1 & 1232.00 & 2400.00 & 1619.58 & 226.79 \\
Pawe-2 & 1200.00 & 2480.00 & 1600.08 & 246.00 \\
Pawe-3 & 1367.00 & 2240.00 & 1767.58 & 223.15 \\
Ethio-Yugoslavia & 1280.00 & 2400.00 & 1723.46 & 267.25 \\
Local variety & 100.00 & 1733.00 & 927.41 & 477.71 \\
\hline
\end{tabular}

Source: Own computation from data, 2020

The combined analysis showed that the mean yield of $1677.68 \mathrm{~kg} \mathrm{ha}^{-1}$ was recorded from hosted farmers' farm plots. On the other hand, $927.41 \mathrm{~kg} \mathrm{ha}^{-1}$ obtained from form local seed users. Grain yield variability was high among local seed users as compared to their counter parts. The result $t$-test $(t=-6.76, p<0.01)$ implies that statistical yield difference observed between improved seed users and non-users at $(\mathrm{p}<0.01)$. The negative sign of t-value (-6.76) indicates that farmers who use local varieties produce less output than improved seed users. 
The finding is similar to(Tufa et al., 2019) who found that grain yield of soybean producers increased by $61 \%$ for farmers who used improved soybean varieties with recommended agronomic packages. The findings of(Abro et al., 2019) also confirmed that use of improved seeds coupled with recommended packages significantly affected crop productivity and efficiency. Use of improved crop varieties significantly and positively affected the quantity of outputs received per hectare(Ahmed et al., 2017). Findings of this study revealed that the grain yield of maize significantly increased for farmers who applied improved maize varieties. Application of improved seeds has a significant and positive effect on grain yield(Meughoyi, 2018). Improved variety seeds significantly and positively increased the productivity of farmers(Tarekegn and Mogiso, 2020). Findings of this study suggest that $35 \%$ yield loss per hectare observed for farmers who used locally available variety seeds. The result is consistent with(Abebe and Alemu, 2017) who found that a significant folds of grain yield increment due to use of improved quality seeds as compared to local variety seeds.

Table 6. Statistical test of the combined mean grain yield

\begin{tabular}{lllll}
\hline variables & Mean Grain yield $\left(\mathrm{kg} \mathrm{ha}^{-1}\right)$ & SD & t-value & Sig. value \\
\hline local seed users & 927.41 & 477.71 & -6.76 & 0.000 \\
improved seed users & 1677.68 & 222.13 & & \\
\hline
\end{tabular}

Source: Own computation from data, 2020

3.3 Yield advantage of improved varieties

The highest $\left(840.17 \mathrm{~kg} \mathrm{ha}^{-1}\right)$ yield increment over the control was recorded from Pawe-3 variety followed by Ethio-Yugoslavia (796.05 kg ha-1). Pawe-1 and Pawe-2 varieties had yield increment of 692.17 and $672.67 \mathrm{~kg}$ $\mathrm{ha}^{-1}$ respectively. The yield difference clearly observed between potential yield and demo yield in all the varieties. The yield difference of potential and demo yield might be due to their performance variability, soil fertility, rainfall and other related factors. Overall, all the evaluated improved soybean varieties had significant yield advantage over the control and can maximize smallholders' income.

Table 7. Yield increment over control $\left(\mathrm{kg} \mathrm{ha}^{-1}\right)$

\begin{tabular}{lllll}
\hline variety & potential yield & Demo yield & Control yield & Yield increment over control \\
\hline Pawe-1 & 2440.00 & 1619.58 & 927.41 & 692.17 \\
Pawe-2 & 2560.00 & 1600.08 & 927.41 & 672.67 \\
Pawe-3 & 2340.00 & 1767.58 & 927.41 & 840.17 \\
Ethio-Yugoslavia & 20.00 & 1723.46 & 927.41 & 796.05 \\
\hline
\end{tabular}

Source: Own computation from data, 2020

\subsection{Farmers' preference of the varieties}

Farmers' were selected purposively based on their experience and knowledge regarding soybean production during field day events to evaluate the varieties accordingly. The evaluation was done at different stages of the crop i.e. vegetative, pod formation and maturity stages to see the potentials of the varieties from different perspectives. Grain yield, seed size, number of pods per plant, seed number per pod, height, disease resistant and maturity date were farmers' preference traits set by evaluators. The result agrees with(Buah et al., 2020) who found grain yield, pod shattering resistant, number of pods per plant and early maturity were the most important farmers preference traits among others for most of the farmers to choose their own variety. During the vegetative and pod formation stage of evaluation, Pawe-1, pawe-2 and pawe 3 varieties were preferred by farmers. EthioYugoslavia was not preferred at these vegetative and pod formation stages. After maturation, farmers ranked the varieties by looking their overall performance based on the preferred traits set by farmers themselves. Although grain yield was the main preference trait for evaluators, the final selection process was based on the total score put by farmers. Pawe-3 and Ethio-Yugoslavia varieties were ranked first regarding their grain yield. High yielder variety is the most preferred varieties by farmers and put yield in the first rank among other traits(Laborte et al., 2015). The findings of(Mutanyagwa et al., 2018) revealed that grain yield is one of the main preference trait for farmers to choose the improved varieties. The result is also in line with(Martey et al., 2021) who confirmed high yield and early maturity traits were the main preference criteria for famers to choose their own improved varieties. Similarly, number of seeds per pod significantly affected grain yield(Buah et al., 2020). Pawe-3 scored the maximum points in most of the preference traits except seed size and got the total score of 24 which is the first preferred variety followed by Ethio-Yugoslavia. Currently, soybean oil processing plants have been established in different parts of the country and Pawe-3 variety has $23 \%$ oil content besides its high productivity. This implies that Pawe- 3 can be the most preferred variety particularly in the edible oil producing plants. 
Table 8. Farmers' preference traits of the varieties

\begin{tabular}{llllllllll}
\hline Variety & Yield & $\begin{array}{l}\text { Seed } \\
\text { size }\end{array}$ & $\begin{array}{l}\text { Pod } \\
\text { No./plant }\end{array}$ & $\begin{array}{l}\text { Seed } \\
\text { No./pod }\end{array}$ & Height & $\begin{array}{l}\text { Disease } \\
\text { resistant }\end{array}$ & $\begin{array}{l}\text { Maturity } \\
\text { date }\end{array}$ & Total & Rank \\
\hline pawe-1 & 3 & 4 & 3 & 3 & 2 & 3 & 3 & 21 & $3^{\text {rd }}$ \\
pawe-2 & 3 & 3 & 3 & 3 & 2 & 3 & 3 & 20 & $4^{\text {th }}$ \\
pawe-3 & 4 & 2 & 4 & 4 & 3 & 4 & 3 & 24 & $1^{\text {st }}$ \\
E.Y & 4 & 2 & 2 & 3 & 4 & 3 & 4 & 22 & $2^{\text {nd }}$ \\
\hline
\end{tabular}

4= Excellent 3=Very good 2= Good 1= Poor

E. $\mathrm{Y}=$ Ethio-Yugoslavia

\section{Conclusion and Recommendations}

The findings of this study concluding that production status is far below from the existing potential although great opportunities exist in the study area. The agro ecology (lands, temperature and rain fall distribution) of western Ethiopia is highly favorable to produce soybean widely. The productivity of the crop in the study area is very low due to lack of using improved soybean varieties with other recommended agronomic packages. Grain yield, seed size, pod number per plant, seed number per pod, height, disease resistant and maturity date were the main preference traits set by farmers during evaluation. Although farmers use all these preference traits to choose their own variety/ies, grain yield is the major preference trait and put in the first rank to evaluate the performance of the varieties. Findings of the evaluation suggest that all the demonstrated (Pawe-1, Pawe-2, Pawe-3 and Ethio-Yugoslavia) varieties have statistically significant yield increment over the control local variety. The maximum mean grain yield $\left(1767.58 \mathrm{~kg} \mathrm{ha}^{-1}\right)$ observed from Pawe-3 variety and put in the first rank based on the total sore recorded during evaluation in all locations.

Nationally, many soybean processing plants which need huge quantity of soybean are under establishing. Therefore, farmers are encouraged to use these improved varieties accordingly to increase their production and productivity further to meet the needs of soybean for domestic processing and export marketing and to contribute in the overall economic growth. Agricultural professionals and other concerned bodies have to give special attention regarding promoting the newly released proven soybean varieties with recommended full packages to enhance the production status of the country and to ensure the demands of currently established soybean processing plants and to save foreign currency through import substitution.

\section{References}

Abebe, G. (2018). Determinants Of Adoption Of Improved Soybean Varieties: The Case Of Chewaka And Gobusayo Districts, Buno Bedele And East Wollega Zones Of Oromia Region, Ethiopia. In "2018 Stata Conference". Stata Users Group.

Abebe, G., and Alemu, A. (2017). Role of improved seeds towards improving livelihood and food security at Ethiopia. International Journal of Research-Granthaalayah 5, 338-356.

Abro, Z. A., Legesse Debela, B., and Kassie, M. (2019). "The joint impact of improved maize seeds on productivity and efficiency: implications for policy." GlobalFood Discussion Papers.

Adebayo, C., Coker, A., and Tsavhemba, S. (2018). Adoption of improved soybean production technologies in Benue State, Nigeria. Nigeria Agricultural Journal 49, 65-70.

Ahmed, M. H., Geleta, K. M., Tazeze, A., and Andualem, E. (2017). The impact of improved maize varieties on farm productivity and wellbeing: Evidence from the east Hararghe zone of Ethiopia. Development Studies Research 4, 9-21.

Ayalew, B., Bekele, A., and Mazengia, Y. (2018). Analysis of Cost and Return of Soybean Production Under Small Holder Farmers in Pawe District, North Western Ethiopia. Journal of Natural Sciences Research 8 , 28-34.

Buah, S., Denwar, N., Kanton, R., and Kombiok, J. (2020). Participatory Approach to Variety Selection Using Soybean Production in Ghana as a Model. West African Journal of Applied Ecology 28, 14-30.

Fedorova, T., Dubrovin, K., and Selezneva, N. (2020). Comparison of productivity indicators for the Far Eastern selection of soybean varieties under adverse climatic conditions with different planting dates. In "IOP Conference Series: Earth and Environmental Science", Vol. 547, pp. 012006. IOP Publishing.

Fentahun, G.-E. (2019). Production and Marketing Trends of Soy Bean in Ethiopia.

Getnet, B. E. (2019). SOYBEAN (GLYCINE MAX L. MERILL) GENETIC IMPROVEMENT IN ETHIOPIA: A REVIEW. International Journal of Research-GRANTHAALAYAH 7, 189-199.

Kedir, M. (2019). Impact of Improved Soybean (Belessa-95) Variety on Income among Smallholder Farmers in Bambasi Woreda, Benishangul Gumuz Regional State.

Khojely, D. M., Ibrahim, S. E., Sapey, E., and Han, T. (2018). History, current status, and prospects of soybean 
production and research in sub-Saharan Africa. The Crop Journal 6, 226-235.

Laborte, A. G., Paguirigan, N. C., Moya, P. F., Nelson, A., Sparks, A. H., and Gregorio, G. B. (2015). Farmers' preference for rice traits: insights from farm surveys in Central Luzon, Philippines, 1966-2012. PLoS One 10, e0136562.

Martey, E., Etwire, P. M., Adogoba, D. S., and Tengey, T. K. (2021). Farmers' preferences for climate-smart cowpea varieties: implications for crop breeding programmes. Climate and Development, 1-16.

Meughoyi, C. T. (2018). Improved seeds and agricultural productivity of family farms in Cameroon. In "Building a Resilient and Sustainable Agriculture in Sub-Saharan Africa", pp. 15-32. Palgrave Macmillan, Cham.

Mutanyagwa, A. P., Isinika, A., and Kaliba, A. R. (2018). The factors influencing farmers' choice of improved maize seed varieties in Tanzania. Int J Sci Res 6, 55-63.

Shea, Z., Singer, W. M., and Zhang, B. (2020). Soybean Production, Versatility, and Improvement. In "Legume Crops-Prospects, Production and Uses". IntechOpen.

Tarekegn, K., and Mogiso, M. (2020). Assessment of improved crop seed utilization status in selected districts of Southwestern Ethiopia. Cogent Food \& Agriculture 6, 1816252.

Tesfaye, M. A., Arega, A., Atero, B., Degu, T., and Hailemariam, M. (2018). Progress of Soybean [Glycine max (L.) Merrill] Breeding and Genetics Research in Ethiopia: A Review. Ethiop. J. Crop Sci. 6, 129-152.

Teshale, W. T. D. (2019). Impact of Improved Soybean Variety on Enhancing Productivity and Gross Farm Income of Smallholder Farmers in North Western Ethiopia.

Tufa, A. H., Alene, A. D., Manda, J., Akinwale, M., Chikoye, D., Feleke, S., Wossen, T., and Manyong, V. (2019). The productivity and income effects of adoption of improved soybean varieties and agronomic practices in Malawi. World development 124, 104631.

Voora, V., Larrea, C., and Bermudez, S. (2020). "Global Market Report: Soybeans," JSTOR. 